\title{
Biomonitoring of river Ganga bank by identifying mollusc species as an indicator
}

\author{
Kaushik Gupta ${ }^{1}$, Abantika Nandy ${ }^{1}$, Kushal Banerjee ${ }^{1}$, \\ Soumendra Nath Talapatra ${ }^{2^{*}}$ \\ ${ }^{1}$ Department of Environmental Science, University of Calcutta \\ 35 Ballygunge Circular Road, Kolkata 700019, India \\ ${ }^{2}$ Career Advancement Solutions H2 - 120A/ New Bener Pole Road \\ Maheshtala, Kolkata 700141, India \\ *E-mail address: ecologylive@yahoo.co.in
}

Keywords: Biomonitoring; bioindicators; mollusc species; pollution; river

\begin{abstract}
The present study deals with biomonitoring to know mollusc species as an indicator. In the present study, presence, absence and abundance of particular gastropod and bivalve species were identified in the different banks of river Ganga. The study was carried out at two experimental sites, Sodepur (Exp-1) and Khardah (Exp-2), West Bengal, India as the area exhibits a major sewage water outfall in the river compared with upstream control site, Kalyani (Cont-1) and downstream control site, Batanagar (Cont-1). The present biomonitoring shows qualitatively and quantitatively that in experimental no mollusc species were observed near the wastewater discharge area into the bank of river Ganga at Khardah while both sites of the sewage discharge area into the bank of river Ganga at Sodepur particular gastropod Bellamya sp. were observed when compared to control area. The highest variety and total nos of gastropods and bivalves (280 nos) were recorded in the upstream at Kalyani and lowest variety and total nos of only gastropods (150 nos) were recorded in the downstream at Batanagar. The present biomonitoring work was a preliminary observation to know sensitive and tolerant or accumulator mollusc species in the bank of river Ganga from a stretch of Kalyani (upstream) to Batanagar (downstream) in between urban wastewater discharge area (Sodepur and Khardah). Further researches must be relevant in relation to biomarker assessment with the physico-chemical factors and stress tolerant detoxification mechanism of particular mollusc species.
\end{abstract}

\section{INTRODUCTION}

Biological monitoring is a tool and can be used as the basis for management programmes, restoring and maintaining the physico-chemical and biological integrity of freshwater (Singh et al., 2014). Live organisms provide valuable information by their presence, absence and abundance regarding their surrounding habitat and can be used to evaluate the local environmental impact by their physical, chemical and biological properties and their cumulative effects (Karr and Chu, 1999). On the other hand, surveys of the richness and species composition, the relative abundance of groups or individual species and the ecological relationships between the inhabiting organisms are the most relevant measure to detect whether a water body meets the biological standards for aquatic biota. To understand their immense importance, several workers have been studied the diversity of macrobenthic invertebrates in aquatic ecosystem in lotic water bodies in the various parts of the globe (Hellawell 1986, Dutta and Malhotra, 1986; Dutta et al., 2000; Sawhney, 2004; Wepener et al., 2005; Mushtaq, 2007; Sawhney, 2008; Sharma and Rawat, 2009; Gupta and Singh, 2011; Sharma and Sharma, 2015).

Generally macroinvertebrates have been well established for biological monitoring efforts because they are diverse group of longed lived, sedentary and used to predicting anthrpogenic influence on aquatic ecosystem (Rosenberg \& Resh, 1993; Gupta and Singh, 2011). The study of macroinvertebrates diversity and water quality parameters are interrelated and indicators of water 
quality by their presence, abundance and absence as tolerant or accumulators and/or sensitive (Hellawell 1986, Wepener et al., 2005; Sharma and Rawat, 2009) and easy to respond to organic and inorganic pollution load (Kazanci \& Dugal, 2000). They have sensitive life stages and respond to acute and chronic environmental stressors and important for maintaining biodiversity (Mayer et al., 2007; Richardson \& Danehy, 2007; Latha et al., 2008, Dhembare, 2011).

The use of mollusc species as biomonitors or bioindicators of heavy metals in coastal zones is well established (Rainbow and Philips, 1993). Although bivalve molluscs have been widely utilized as biomonitors (Goldberg et al., 1983), gastropod molluscs like patellid limpets or top-shell snails are increasingly employed in a similar activity (Nicolaidou and Nott, 1998; Cubadda et al., 2001; Solanki et al., 2003; Hamed and Emara, 2006). It was studied that gastropods are dominant group of molluses in Iskenderun Bay (Bakir et al., 2012). Some studies have been published on determination of trace metals and contaminants in gastropod molluscs Patella caerulea from Iskenderun Bay (Türkmen et al., 2005; Yüzereroğlu et al., 2010). But no one has attempted biomonitoring of the bank of river Ganga from Kalyani to Batanagar stretch before to know particular gastropod species as suitable indicators for sewage water.

The present study aims to know particular gastropod species as suitable indicators on the basis of their presence, absence and abundance for sewage wastewater mixing area at the different bank of river Ganga.

\section{MATERIALS AND METHODS STUDY AREA:}

The study was carried out at experimental sites, Sodepur (Latitude $=22^{\circ} 41^{\prime} \mathrm{N}$ and Longitude $=88^{\circ} 21^{\prime} \mathrm{E}$ ), West Bengal, as the area exhibits a major sewage water outfall in the river, Secondly, at Khardah (Latitude $=22^{\circ} 43^{\prime} \mathrm{N}$ and Longitude $=88^{\circ} 21^{\prime} \mathrm{E}$ ), an industrial belt, exhibiting industrial effluent outflow in the river. These two sites (experimental as Exp-1 \& Exp-2) were compared with upstream control site (Cont-1), Kalyani (Latitude $=22^{\circ} 59^{\prime} \mathrm{N}$ and Longitude $=88 .^{\circ} 24^{\prime} \mathrm{E}$ ) and downstream control site (Cont-2), Batanagar (Latitude $=22^{\circ} 30^{\prime} \mathrm{N}$ and Longitude $=88^{\circ}{ }^{\circ} 12 .^{\prime} \mathrm{E}$ ). There were no sewage water discharge in these control area. All four sites are located in the Ganges river Basin in West Bengal, finally meeting at the Bay of Bengal. The satellite image of the study area is given in Fig. 1A, B, C and D.

\section{FIELD STUDY:}

The Study was carried out between December, 2014 and January, 2015 (winter season) during low tide conditions, in the mud flats of the river Ganga. The study was based on presence, abundance and absence of molluscs species in relation sewage wastewater discharge area at the bank of Ganga river compared to control area (no sewage discharge area). The duration of the study was one month and in each week the study was done on one site. Qualitative and quantitative assessment of the molluscs species especially gastropods and bivalves was studied by using $1 \mathrm{ft} x 1 \mathrm{ft}$ quadrates. Quadrates were laid 10 times randomly on the mud-flats and the species were observed according to their presence, abundance, absence and behaviour. Species were observed during the study, were recorded for identification by visual observation and image capture during study. 


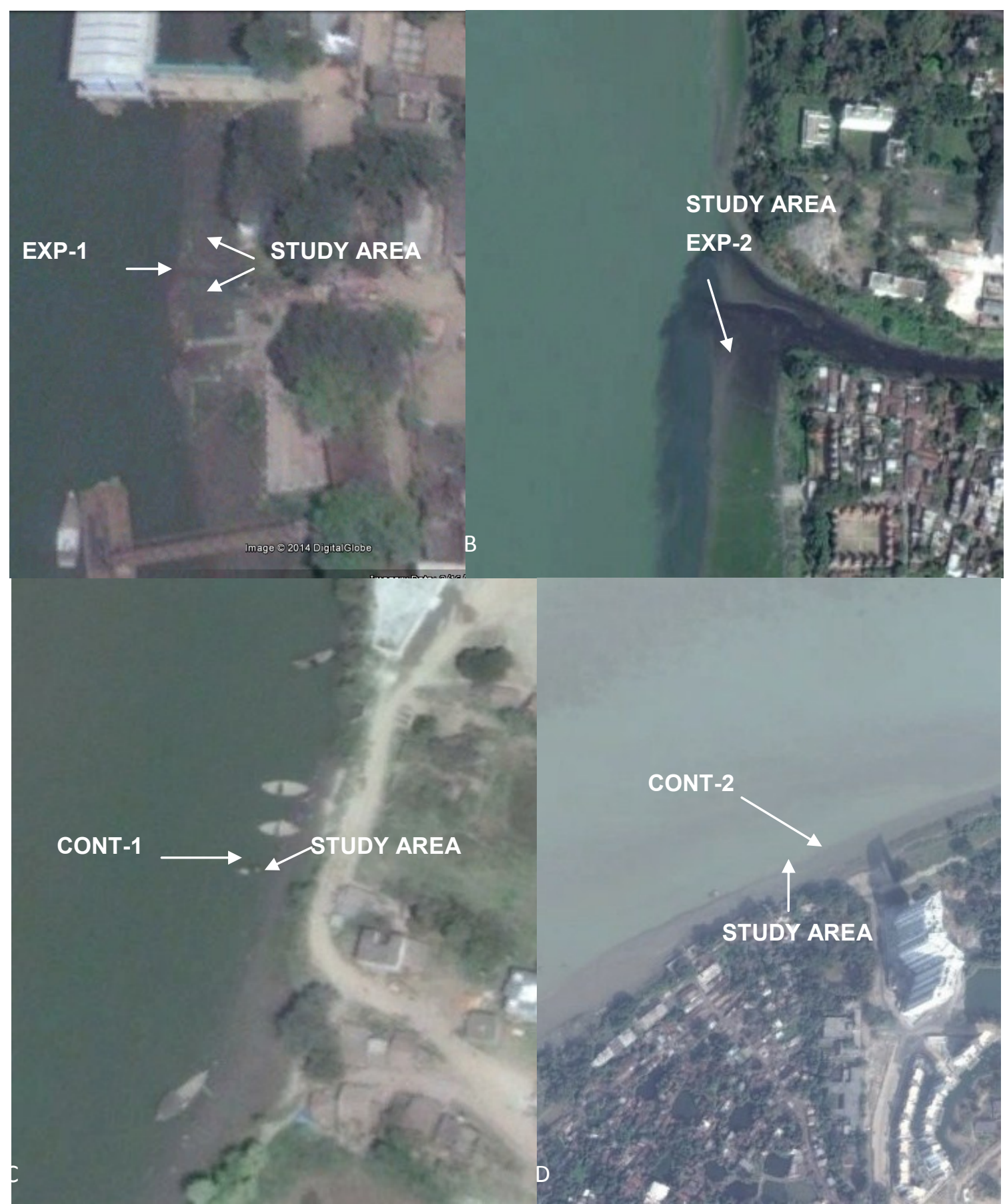

Fig 1. Satellite image for study area $A=$ Sodepur (EXP-1); $B=$ Khardah (EXP-2); $C=$ Kalyani (upstream, CONT-1) and D = Batanagar (downstream, CONT-2)

\section{RESULTS}

The results for biomonitoring clearly revealed that no mollusc species were observed near the wastewater discharge area into the bank of river Ganga at Khardah while both sites of the another sewage discharge area into the bank of river Ganga at Sodepur were only found particular gastropod species, Bellamya sp. (total population of 18 nos were found in the left side and 65 nos of were observed in the right side). In the control area, highest variety and total population were 280 nos of gastropods (Thiara sp., Hydrobia sp. Gyraulus sp. and Bellamya sp.) and bivalves (Parreysia sp.) were recorded in the upstream at Kalyani and lowest variety and total 150 nos of only gastropods (Bellamya sp. and Bithynia sp.) were recorded in the downstream at Batanagar (Table 1). It was observed no wastewater discharge in the control area. 
Table 1. Qualitative and quantitative study of molluscs as bioindicators in the bank of river Ganga

\begin{tabular}{|c|c|c|c|c|}
\hline SI. No. & Study area & $\begin{array}{c}\text { Quadrates } \\
\text { laid }\end{array}$ & $\begin{array}{l}\text { Type and no. Individual } \\
\text { species observed }\end{array}$ & $\begin{array}{l}\text { Total no. of population } \\
\text { in each quadrate }\end{array}$ \\
\hline \multirow[t]{10}{*}{1.} & \multirow[t]{10}{*}{ Sodepur Left } & 1 & Bellamya sp. $=2$ & 02 \\
\hline & & 2 & Bellamya sp. $=2$ & 02 \\
\hline & & 3 & Bellamya $\mathrm{sp} .=3$ & 03 \\
\hline & & 4 & Bellamya sp. $=2$ & 02 \\
\hline & & 5 & Bellamya sp. $=5$ & 05 \\
\hline & & 6 & Bellamya sp. $=2$ & 02 \\
\hline & & 7 & Bellamya sp. $=1$ & 01 \\
\hline & & 8 & Bellaiya sp. $=1$ & 01 \\
\hline & & 9 & 0 & 0 \\
\hline & & 10 & 0 & 0 \\
\hline \multicolumn{4}{|c|}{ Total population nos. $=$} & 18 \\
\hline \multirow[t]{10}{*}{2} & \multirow[t]{10}{*}{ Sodepur Right } & 1 & Bellamya sp. $=7$ & 07 \\
\hline & & 2 & Bellamya sp. $=4$ & 04 \\
\hline & & 3 & Bellamya sp. $=6$ & 06 \\
\hline & & 4 & Bellamya sp. $=4$ & 04 \\
\hline & & 5 & Bellamya sp. $=4$ & 04 \\
\hline & & 6 & Bellamya sp. $=6$ & 06 \\
\hline & & 7 & Bellamya sp. $=22$ & 22 \\
\hline & & 8 & Bellamya sp. $=1$ & 01 \\
\hline & & 9 & Bellamya sp. $=1$ & 01 \\
\hline & & 10 & Bellamya sp. $=10$ & 10 \\
\hline \multicolumn{4}{|c|}{ Total population nos. $=$} & 65 \\
\hline \multirow[t]{10}{*}{3.} & \multirow[t]{10}{*}{ Khardah } & 1 & 0 & 0 \\
\hline & & 2 & 0 & 0 \\
\hline & & 3 & 0 & 0 \\
\hline & & 4 & 0 & 0 \\
\hline & & 5 & 0 & 0 \\
\hline & & 6 & 0 & 0 \\
\hline & & 7 & 0 & 0 \\
\hline & & 8 & 0 & 0 \\
\hline & & 9 & 0 & 0 \\
\hline & & 10 & 0 & 0 \\
\hline \multicolumn{4}{|c|}{ Total population nos. $=$} & $\mathbf{0}$ \\
\hline \multirow[t]{10}{*}{4.} & \multirow[t]{10}{*}{ Kalyani } & 1 & Bellamya sp. $=20$ & 20 \\
\hline & & 2 & Bellamya $\mathrm{sp} .=30$ & 30 \\
\hline & & 3 & Bellamya sp. $=32$ & 32 \\
\hline & & 4 & Bellamya sp. $=21$ & 21 \\
\hline & & 5 & Bellamya sp. $=22$ & 22 \\
\hline & & 6 & $\begin{array}{l}\text { Thiara } \mathrm{sp} .=1 ; \text { Bellamya } \mathrm{sp} .= \\
29\end{array}$ & 30 \\
\hline & & 7 & Bellamya sp. $=24$ & 24 \\
\hline & & 8 & $\begin{array}{l}\text { Parreysia } \text { sp. }=1 ; \text { Bellamya } \mathrm{sp.} \\
=31 ; \text { Pila } \mathrm{sp} .1\end{array}$ & 33 \\
\hline & & 9 & $\begin{array}{l}\text { Gyraulus sp. }=1 ; \text { Bellamya sp. } \\
=28\end{array}$ & 35 \\
\hline & & 10 & $\begin{array}{l}\text { Bellamya sp. }=32 ; \text { Hydrobia } \\
\text { sp. }=10\end{array}$ & 33 \\
\hline \multicolumn{4}{|c|}{ Total population nos. $=$} & 280 \\
\hline \multirow[t]{4}{*}{5.} & \multirow[t]{4}{*}{ Batanagar } & 1 & $\begin{array}{l}\text { Bithynia sp. }=8 ; \text { Bellamya } \mathrm{sp} .= \\
11\end{array}$ & 19 \\
\hline & & 2 & $\begin{array}{l}\text { Bithynia sp. }=3 ; \text { Bellamya } \text { sp } .= \\
4\end{array}$ & 07 \\
\hline & & 3 & $\begin{array}{l}\text { Bithynia sp. }=6 ; \text { Bellamya } \text { sp. }= \\
8\end{array}$ & 14 \\
\hline & & 4 & $\begin{array}{l}\text { Bithynia } \mathrm{sp} .=4 ; \text { Bellamya } \mathrm{sp} .= \\
12\end{array}$ & 16 \\
\hline
\end{tabular}




\begin{tabular}{|l|l|l|l|}
\hline \multirow{2}{*}{} & 5 & $\begin{array}{l}\text { Bithynia } \text { sp. }=4 ; \text { Bellamya } \text { sp. }= \\
7\end{array}$ & 11 \\
\cline { 2 - 4 } & 6 & Bellamiya sp. $=4$ & 04 \\
\cline { 2 - 4 } & 7 & $\begin{array}{l}\text { Bithynia } \text { sp. }=7 ; \text { Bellamya } \text { sp. }= \\
11\end{array}$ & 17 \\
\cline { 2 - 4 } & 8 & Bellamya sp. $=13$ & 13 \\
\cline { 2 - 4 } & 9. & $\begin{array}{l}\text { Bithynia } \text { sp. }=9 ; \text { Bellamya } \text { sp. }= \\
28\end{array}$ & 37 \\
\cline { 2 - 4 } & 10 & $\begin{array}{l}\text { Bithynia } \text { sp. }=4 ; \text { Bellamiya } \text { sp. } \\
=8\end{array}$ & 12 \\
\hline Total population nos. $=$ & & $\mathbf{1 5 0}$ \\
\hline
\end{tabular}

\section{DISCUSSION}

The physico-chemical analysis of the habitat of biota through medium such as water, sediment and mud is the most direct approach to detect the heavy metals and organics pollution status in the environment, while it cannot afford the powerful evidence on the integrated influence and possible toxicity of such pollution on the biota and ecosystem. Biomonitoring is a scientific technique for assessing environment including human exposures to natural and synthetic chemicals, based on sampling and analysis of an individual organism's presence, abundance and absence alongwith cells, tissues and fluids alterations to know biomarkers. Due to consistency between the selected organisms and the corresponding habitat, biomonitoring can directly offer the data on the potential effects and actual integrated acute and chronic toxicities of metals and organics pollutants, reflecting the deleterious degree of impacts in the environment (Zhoua et al., 2008).

Various metal accumulating bivalve and gastropod species showed presence, abundance and absence in marine and freshwater reverine ecosystems, therefore they are monitored as suitable indicators in several monitoring projects for metals viz. $\mathrm{Cd}, \mathrm{Cr}, \mathrm{Zn}$ in Perumytilus purpuratus, Semelle solida and Tagellus dombeii (Gregori et al., 1996). The benthic and surface molluscs play an important role as bioindicators for trace metal pollution and appear more and more often in global monitoring programs (Rainbow et al., 2000). According to Salanki (1986), in biological monitoring, molluscs species have occupied a prominent place and they are often used both for passive and active biomonitoring and also in ecological risk assessment among other aquatic organisms. In recent years, researchers have focused their attention on the identification of suitable bioindicators for trace metal pollution, especially the gastropod molluscs. Several biomonitoring studies for the heavy metals pollution in aquatic ecosystem, have been carried out in past two decades using different mollusc species, gastropod mollusc species, Bembicium nanum, bivalve species, Pyganodon grandis, Crassostrea angulata, Scrobicularia plana, Melicertus kerathurus, Crassostrea virginica, Radix ovata and Viviparus spp., Rapana venosa and Neverita didyma (Blasco et al., 1999; Gundacker, 2000; Gay and Maher, 2003; Apeti et al., 2005; Bonneris et al., 2005; Lee et al., 2006). The biomonitoring is necessary to identify a wider range of bioindicators and thus expand current understanding of different bioaccumulation strategies for trace metals (Solanki et al., 2006). In the present study, it was observed that Bellamya sp. can tolerate pollutants of sewage wastewater by their moderate population nos at Sodepur while no mollusc species were observed at Khardah may be due to the presence of metals and other toxicants when compared to Kalyani (upstream) and Batanagar (downstream) control area. The present study indicates mollusc species were sensitive indicator by their unavailability at EXP-2 site. According to Vazirizadeh and Iman, (2011), sewage wastewater also contains some organic compounds and toxicants. Sharma and Sharma (2015) have reported that only one gastropod species, Gyraulus sp. as pollution resistant was found in sewage contaminated riverine area. Similar observations were found in the present study that other mollusc species were sensitive except Bellamya sp. as tolerant or accumulator indicator in the Sodepur area (EXP-1) and may be due to the absence of metals and presence of organic pollutants. It was already reported that sewage water contains appreciable amounts of metals and algae were potent accumulator of these metals. In the bank of river Ganga at Khardah 
area algae were observed majorly and no mollusc species were found as like other research work (Rai et al., 2012).

\section{CONCLUSION}

In conclusion, various species of gastropods and bivalves molluscs have been recognized as a useful tool for monitoring of heavy metals and organics pollution. These organisms accumulate comparatively higher concentrations of metals because of their sedentary nature, both from water and sediment. In biomonitoring, the extent of bioaccumulation thus can play key role in determining water and sediment quality criteria. Molluscs species occupy the important position in food chain and are ubiquitous and abundant, live in a sessile style thus represents the pollution level of habitat. They also satisfy the other conditions to be bioindicators like their presence, abundance, absence and easy identification. There are suitable to measure for water quality assessment. Molluscs are also suitable sensitive and tolerant to environmental alterations, and various contaminants (Sharma and Sharma, 2015). In the present study, Bellamya sp. was found as tolerant or accumulator indicator in the Sodepur area (EXP-1) and may be due to the absence of metals and presence of organic pollutants. This was a preliminary study to identify sensitive and tolerant or accumulator mollusc species in the bank of river Ganga on the basis of biomonitoring from a stretch of Kalyani (upstream) to Batanagar (downstream) in between urban wastewater discharge area (Sodepur and Khardah). Further researches must be relevant in relation to biomarker assessment with the physicochemical factors and stress tolerant detoxification mechanism of particular mollusc species.

\section{Acknowledgement}

The authors convey their gratitude to the local people of the area for continuous help and support for doing this study. Also thankful to Dr. Pranabes Sanyal, Visiting Professor, School of Oceanography, University of Jadavpur for helping in the identification of mollusc species.

\section{References}

[1] Apeti D.A., Johnson E., Robinson L., American J Environ Sci 1 (2005) 239-248.

[2] Bakir B.B., Öztürk B., Doğan A., Önen M., Turk J Fish Aquat Sci 12 (2012) 171-184.

[3] Blasco J., Arias A.M., Saenz V., Sci Tot Environ 242 (1999) 249-259.

[4] Bonneris E., Giguere A., Perceval O., Buronfosse T., Masson S., Hare L., Campbell P.G.C., Aquat Toxicol 71(2005) 319-334.

[5] Cubadda F., Conti M.E., Campanella L., Chemosphere 45 (2001) 561-569.

[6] Dhembare A.J., Adv Appl Sci Res 2 (6) (2011) 223-228.

[7] Dutta S.P.S., Malhotra Y.R., Indian J Ecol 113 (1) (1986) 138-145.

[8] Dutta S.P.S., Malhotra Y.R., Sharma K.K., Sinha K., Him J Environ Zool 14 (2000) 13-24.

[9] Duysak O., Ersoy B., Pakistan J Zool 46 (5) (2014) 1317-1322.

[10] Gay D., Maher W., Wat Res 37 (2003) 2173-2185.

[11] Gregori I.D., Pinochet H., Gras N., Mufioz L., Environ Poll 92 (1996) 359-368.

[12] Gundacker C., Environ Poll 110 (2000) 61-71.

[13] Hamed M.A., Emara A.M., J Mar Syst 60 (2006) 220-234.

[14] Hellawell J.M., Biological indicators of freshwater pollution and environmental management. (Pollution Monitoring Series) London: Elsevier Applied Science Publishers, p. 546 (1986).

[15] Karr J.R., Chu E.W., Restoring life in running waters - Better biological monitoring. Washington, Island Press, p. 206 (1999). 
[16] Kazanci J.B., Dugal M., Water Sci Techno 47 (2000) 7-8.

[17] Latha C., Thanga V.S.G., Macroinvertebrate Diversity: A tool for Biomonitoring selected Reaches of Kallar, a Tropical Mountain streamin South Kerala, India. Proceedings of Conference on Mountains of the world, Ecology, Conservation and Sustainable Development, Muscut, Sultanate of Oman 10-14 February, p. 25 (2008).

[18] Lee C.S., Li X., Shi W., Cheung S.C. Thornton I., Sci Tot Environ 356 (2006) 45-61.

[19] Mayer J.L., Strayer D.L., Wallace J.B., Eggert S.L., Helfman G.S., Leonard N.E., J American Water Res Assoc 43 (1) (2007) 86-103.

[20] Mushtaq R., Impact of urban influences on the diversity of macrobenthic invertebrate fauna of River Tawi. M.Phil Dissertation, University of Jammu, Jammu (2007).

[21] Nicolaidou A., Nott J.A., Mar Pollut Bull 36 (1998) 360-365.

[22] Rai U.N., Prasad D., Verma S., Upadhyay A.K., Singh N.K., Bull Environ Contam Toxicol 89(4) (2012) 805-810.

[23] Rainbow P.S., Phillips D.J.H., Mar Pollut Bull 26 (1993) 593-596.

[24] Rainbow P.S., Wolowicz M., Fialkowski W., Smith B.D., Sokolowski A., Wat Res 34 (2000) 1823-1829.

[25] Richardson J.S., Danehy R.J., Forest. Sci 53 (2007) 131-147.

[26] Rosenberg D., Resh V., Freshwater Biomonitoring and Benthic macroinvertebrates. Chapman Hall Publ (1993).

[27] Salanki J., Biological monitoring of the state of the environment: Bioindicators I.U.B.S. Monograph series No. 1 for I.C.S.U. by I.R.L. (1986).

[28] Sawhney N., Limnology of ban Ganga stream (Katra) with special reference to some consumers inhabiting the stream. M. Phill. Dissertation, University of Jammu, Jammu (2004).

[29] Sawhney N., Biomonitoring of River Tawi in the vicinity of Jammu City. Ph.D. Thesis. University of Jammu, jammu (2008).

[30] Sharma C., Rawat J.S., Eco Indicat 9 (2009) 118-128.

[31] Sharma A., Sharma V., Indian J Appl Res 5 (1) (2015) 203-205.

[32] Singh R., Singh V.K., Dwivedi A.K., Biolife 2(1) (2014) 297-305.

[33] Solanki J., Farkas A., Kamardina T., Rozsa K.S., Toxicol Lett 141 (2003) 403-410.

[34] Türkmen M., Türkmen A., Akyurt I., Tepe Y., Bull Environ Contam Toxicol 74 (2005) 301307.

[35] Vazirizadeh A., Iman A., World J Fish Mar Sci 3 (2) (2011) 174-182.

[36] Wepener V., Van Vuren J.H.J.., Chatiza F.P., Mbizi Z., Sla L., Phys Chem Earth 30 (2005) 751-761.

[37] Yüzereroğlu T.A., Gök G., Coğun H.Y., Firat O., Aslanyavrusu S., Maruldali O., Kargin, F., Environ Monit Assess 167 (2010) 257-264.

[38] Zhoua Q., Zhanga J., Fua J., Shia J., Jiang G., Ana Chim Acta 606 (2008) 135-150. 